\title{
The Effect of Roundtable and Clustering Teaching Techniques and Students' Personal Traits on Students' Achievement in Descriptive Writing
}

\author{
Megawati Sinaga* \\ English Applied Linguistics Study Program Postgraduate School, State University of Medan, Indonesia
}

Correspond Author: Megawati Sinaga, E-mail: megawati21.sinaga71@gmail.com

\section{ARTICLE INFO}

\section{Article history}

Received: August 28, 2017

Accepted: October 22, 2017

Published: December 30, 2017

Volume: 8 Issue: 6

Advance access: December 2017

Conflicts of interest: None

Funding: None

\section{Key words:}

Teaching Techniques,

Personal Traits,

Descriptive Writing

\begin{abstract}
The Objectives of this paper as an experimental research was to investigate the effect of Roundtable and Clustering teaching techniques and students' personal traits on students' achievement in descriptive writing. The students in grade ix of SMP Negeri 2 Pancurbatu $2016 / 2017$ school academic year were chose as the population of this research. The research design was experimental research by using factorial design $2 \times 2$. The students were divided into two experimental groups. The experimental group was treated by using Roundtable teaching technique and control group was treated by using Clustering teaching technique. The students are classified into the introvert and extrovert personal traits by conducting the questionnaire and the students' achievement in descriptive writing was measured by using writing test, namely 'Analytic Scoring' by Weigle. The data were analyzed by applying two-way analysis of variance (ANOVA) at the level of significance $\alpha=0.05$. The result reveals that (1) students' achievement in descriptive writing taught by using Roundtable teaching technique was higher than that taught by Clustering teaching technique, with Fobs $=4.59>\mathrm{Ftab}=3.97$, (2) students' achievement in descriptive writing with introvert personal trait was higher than that with extrovert personal traits with Fobs $=4.90>$ Ftable $=3.97$, (3) there is interaction between teaching techniques and personal traits on students' achievement in descriptive writing with Fobs $=6,58>$ Ftable $=3.97$. After computing the Tuckey-Test, the result showed that introvert students got higher achievement if they were taught by using Roundtable teaching technique while extrovert students got higher achievement if they were taught by using Clustering teaching technique.
\end{abstract}

\section{INTRODUCTION}

Writing is more than a medium of communication. It means that writing is not just the way to communicate to each other but also as means of ideas and emotional expressions (Raymond, 1980). The word becomes permanent by writing, and as the expanding of the various memory of human being. By writing the people can see what are in someone thought because it is visible and permanent whereas spoken words disappear after they are spoken. Different from spoken words, writing quality can be examined and tested. So writing is a way of remembering and a good way to do the communication because by writing, the writer really thinks about what to be communicated by writing it.

Writing is very important in today's world life, as Graham (2006) stated that students who do struggle significan ly with writing, and adults who cannot or will not engage in writing, are at a terrible disadvantage in today's world. If someone do not write well he will find the difficulties in learning process, education and employment.The same idea is also noted by Boardman (2008: 3) that the paragraph is the basic unit of academic writing in English. Students who want to study in a collage or in a university or to get a certain job, need to learn how to write, because all other types of academic writing, such as reports, essays, compositions and research papers are based on the paragraph of a writing text.

Students in Indonesia have been taught writing course since they were in the first class of Junior High School. But, it was found that they face some difficulties in writing. As Hazanah (2003) found that commonly, students are difficult in starting the writing, they got confuse about what to write and also about how to generate ideas. This is because of the lack of knowledge about the steps on writing was procedural factors that cause the difficulties for all students. And the most important thing is that, writing is usually get least attention in teaching learning in classroom, which make students are rarely exposed to writing.

This matter also happens to the students in SMP Negeri 2 Pancurbatu. As the researcher has observed the students in that school, the researcher found that many students think that it is because the ability in writing can be achieved through a lot of practice and process. Most of researchers recognize this difficulty in writing is caused by the complexity of writing (Urquhart, 2005).

The researcher got the score in writing course is low. The scores are taken from the written test in the final semester 
test. Relevance to that case, it is needed a significant way of teaching and learning in order to improve the achievement of the students in writing. However in reality the teachers always use the conventional ways of teaching like giving some questions, discussion and homework without any challenges activities that will train their brain to think critically.

Based on the explanation on the background of the study before, the objectives of the research are formulated as in the following:

- To find out whether the students' achievement in writing taught by using Roundtable teaching technique is higher than taught by using Clustering teaching technique.

- To find out whether the students' achievement in writing with introvert personal traits is higher than the students with extrovert personal traits.

- To find out whether there is an interaction between techniques of teaching and personal traits.

Those research objectives are formulated to answer the following problems of the research:

a. Is the students' achievement in writing taught by using Roundtable teaching technique higher than taught by using Clustering teaching technique?

b. Is the students' achievement in writing with introvert personal trait higher than students with extrovert personal trait?

c. Is there any interaction between teaching techniques and personal traits in teaching writing?

The scope of the research is confined in using Roundtable and Clustering teaching techniques as teaching techniques in teaching writing. They will be related with the personal traits of the students in the classroom which is limited to only introvert and extrovert on students' writing achievement. The writing genre observed in this study focuses on descriptive writing which should be achieved by the students of grade nine as what is required to be learnt in curriculum in SMP N 2 Pancurbatu.

\section{REVIEW OF LITERATURE}

\section{Writing}

Writing is a complex process that allows writers to explore thoughts and ideas and make them visible and concrete. Nazario et al, (2010:5) stated that writing is a form of thinking. Our brains process ideas in different ways; mathematically, musically and visually. But our use of language is the basis of all thinking.

Henning (2005) stated that writing is not to be viewed as a representation of a writer's thinking, but as a process of thinking that uses written language, and also as observable performance of what goes on in the mind of author (how the author uses knowledge for inquiry).

\section{Descriptive Writing}

Descriptive writing is a written text in which the writer describes an object through the sensory experience- how something looks, sounds and tastes Kane (2000: 351). The text could be written as the result of experience by seeing, hear- ing, or touching. In descriptive writing, a writer may describe things, perceptions and feelings about something. In addition, Zemach (2000:25) stated that a descriptive paragraph can be a description of people, places and processes. It means that how something or someone feels or looks and how something's done could be explained in a descriptive paragraph.

It is concluded that descriptive writing is a written text that gives a reader a mental picture of the subject that the writer is exploring that it can be a person, an object or it can be about any topics. In descriptive writing, they are described by how it looks feels, sounds, smells or tastes.

Components of Descriptive Writing according to Knapp (2005:99) containing two components, the generic structure and significant lexicogrammatical features. Generic structure is divided to two, identification (the description or the identification of the phenomenon) and description (the description of parts, characteristics, and qualities). The first step in writing generic structure is the writer identifies which phenomenon should be described, and then the description of each part, qualities and the characteristics of the topic. Whereas Significant Lexicogrammatical Features means the sensory language which shares what the writer hears, sees, smells, tastes, and touches. The descriptive writing also uses precise language, including the good verbs and noun. Then, a logical organization, including the order and chronological should be arranged correctly. The using of tense, relational verbs, action verbs, mental verbs, adjectives, adverbs, etc must be written according to its function. When someone focuses his or her mind in description writing, it would be as the recreation the experiences then it is shared with others.

\section{Factors Affecting Good Writing}

A good writing should have process that is steps where a writer goes through until she or he could produce something in its final written form. This process may of course, be affected by the subject matter, the type and the medium of the writing. The process of good writing has four steps (Harmer 2004:6), they are:

1. Planning: in this first step, the writers plan what she or he is going to write, and decide what will be expressed, included the detailed notes.

2. Drafting: the second step, the writers make the draft. A number of drafts may be produced before it is edited in final version

3. Editing; the third step is the writers read through what they have written and check where it works and where it doesn't.

4. Final Version; in this fourth step the writers made the changes they consider to be necessary and they produce their final version. Besides that, there are many other things to be considered in order to be good at writing, such as grammar, words in use, punctuation. (Manser 2006:97).

\section{Roundtable Teaching Technique}

Roundtable is one of teaching technique which is implemented by cooperative learning approach. To reach the high 
quality group work all the members of group must be cooperative as the social skills should be developed. Roundtable is a technique which can be used for brainstorming, reviewing, or practicing skill while also serving as a team builder.

Ekap (2010) noted that Roundtable teaching technique is a technique requires a group or team working in the teaching learning process which requires all the members of group have to be ready to explain their group's answer(s). It means that the answers are produced by the togetherness of the group. While the students give the response, they help their group and group mates indirectly. It can concluded that Roundtable teaching technique is a technique of brainstorming, reviewing or practicing skill in writing which is used to stimulate creativity and deeper thinking as the value of multiple view points and ideas as the result working in team.

In Roundtable teaching technique, all the group member's ideas are used to elaborate, explain, and as then argumentative reason in modifying and restructuring their own thinking and knowledge.

The advantages of using Roundtable teaching technique according to Inglehart et al., 2003:192), can be seen in the Table 2.1 below;

Most of the students face the difficulties in writing, especially in descriptive writing, so by using Roundtable teaching technique, as one of cooperative learning, must be very useful and helpful for the students. They may help each other and work together to produce a good descriptive writing.

\section{Clustering Teaching Technique}

Clustering is the result of active design mind participation that brings to the writing process an awareness of having grouped together, connected and related elements of an idea out of the infinite possibilities available to our brai

Rico (2000:5) noted that when students express the ideas, their paper might look something like the following Figure 1:

From the model above, it can be seen that this writer had the most ideas about the first house the writer lived in as a child. When he thought more about his house, he remembered a stairway in the house and a mysterious lady at the top of it. The large number of circles in stairway means the large ideas about it, and it causes him or her to choose it as the topic of the writing.

The advantages of Clustering Teaching Technique are: (1)helps the writers to see and to make a connection of ideas, to develop those ideas and to trace through the writer's mind until in some points arrive in certain concept. (2) Helps students in gathering and developing ideas, and writing down in a certain concept.

Clustering Teaching Technique is a powerful tool or technique that helps writers to arrange, generate and develop the writers' ideas in order to product a good writing. Rico (2000) stated that Clustering Teaching Technique is a technique for by passing the writer's logical, orderly sign-mind consciousness to touch the mental life of day dream, random thought, image and sensation.

\section{Personal Traits}

Deary (2009: 94) stated that a trait is functionally independent of its origins. Deary then explains that "personal trait is a conceptual attribute, or definition of the reactive nature of the individual. Personality also includes aspects that are concealed from yourself, or unconscious, as well as that are conscious and well within your awareness.

Table 2.1. The Advantages of using Roundtable teaching technique

\begin{tabular}{ll}
\hline $\begin{array}{l}\text { Primarily } \\
\text { cognitive }\end{array}$ & $\begin{array}{l}\text { The students are able to understand and be aware how others write and learn. Their perception, } \\
\text { reasoning and judgment about the subject matter could be shared each other. } \\
\text { Primarilys } \\
\text { substantive }\end{array}$ \\
$\begin{array}{l}\text { Primarily } \\
\text { Thotional/psychological }\end{array}$ & $\begin{array}{l}\text { The students' mental or emotional are enhanced, because they get to know each other better, } \\
\text { and overcome the problem of disagreements. Besides, they may support each other by working } \\
\text { together. }\end{array}$ \\
\hline
\end{tabular}

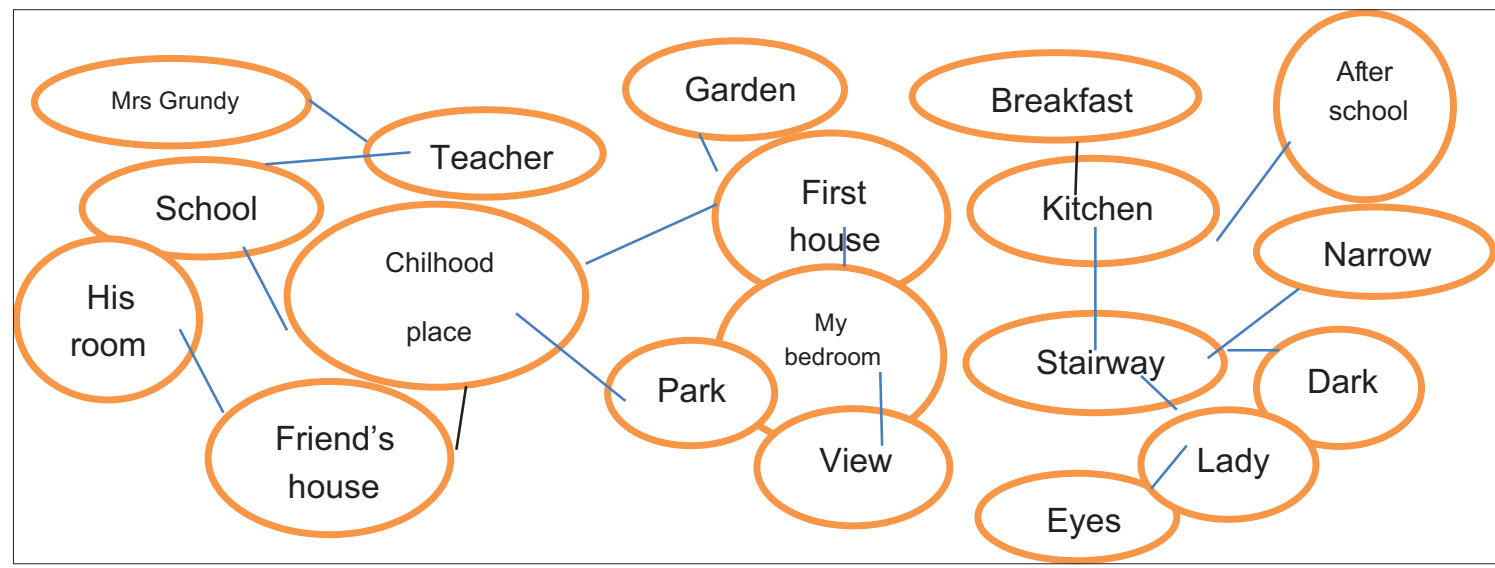

Figure 1. Model of Clustering by Rico (2000) 
Personal traits is the characteristic includes virtually everything about person - mental, emotional, which is stable over time and are different among people, that influence one's behavior that torn by conflicting wishes and goals, and has the components of ego and super ego.

\section{Introvert}

Brown (2007: 167) stated that "introvert can have an inner strength of character that extrovert do not have". Introversion defined as the state of tendency one's own mental life in being wholly or predominantly.

Introversion, on character that extroverts do not have the other hand, is the extent to which a person derives a sense of wholeness and fulfillment apart from reflection of this self from other people.

\section{Extrovert}

Extrovert is the extent to which a person has a deep-seated need to receive ago enhancement, self-esteem and a sense of wholeness from other people as opposed to receiving that affirmation within oneself (Brown 2007: 166). When a person has the ability to turn the energies and interests of the mind toward things, events and people around us, they are classified in to extraversion or extroversion

Extroverts tend to demand the attention and do not have the high tendency in arousal. These kinds of person prefer to do the work in-group rather than individual.

\section{The difference between introvert and extrovert}

Introverts and extroverts are differentiated by the former more interested in what is happening in surrounding. Introverts seldom like anyone invading it and seek their own personal space whereas extroverts tend to welcome anyone with smile on their face and more into socializing. Usually, extroverts have more friends than introverts because introverts don't even like unexpected guests.

Naik (2010) and Laney (2002) stated that introverts have inside motivation and very quiet people, they are systematic and tend to avoid risks. They like to write and read rather than to talk and show up. Their habitual pro- vides them much time in writing than talking. Furthermore, Richard and Schmidt (2002) report that an introvert likes to listen, think, stay with their ideas, and does not like to share with their friends in the classroom. That's why they prefer to do their work individually rather than in group. Consequently, an extrovert is the opposite of introvert in terms of their way of learning and also their personality in their daily life.

Extrovert usually makes more mistakes in compound cognitive tasks such as writing, while introverts are more careful even though they do it slowly. Introverts really avoid the punishment, so they are more cautious and more carefully.

\section{Relevant Studies}

There are some researches who had done a research about Roundtable Teaching Technique, Clustering Teaching Technique and personality. First, Styati (2010) did a research about clustering teaching technique to descriptive writing. The research was carried out at IKIP PGRI Madiun from March to July 2010. It was an experimental research and the result of the study leads to the conclusion that the students who are taught by using clustering teaching technique has better writing ability than those who are taught using direct instruction. In other word, it is more effective to use of Clustering Teaching Technique during teaching learning process than direct instruction.

Second, Ratnawati (2011) who did a research about roundtable teaching technique to teach hortatory exposition. She found that the use of roundtable teaching technique can affect the students' writing ability. The third is Handayani (2012) who had made a research in SMA N 1 Ngaglik, Sleman in the academic year 2011/2012 about Roundtable Teaching Technique in learning descriptive writing. She found that the students' who are taught using Roundtable Teaching Technique have better writing skill than those who are taught using direct instruction. In other words, the use of Roundtable Teaching Technique is more effective than direct instruction. Therefore, it is interesting and exciting when this research is attempted to combine both teaching techniques with students' personality.

Table 2.2. The difference between Introvert and Extrovert by Ewen (2003)

\begin{tabular}{ll}
\hline $\begin{array}{l}\text { Functions } \\
\text { Thinking }\end{array}$ & $\begin{array}{l}\text { Extrovert } \\
\text { Interpreting and understanding the external world } \\
\text { aspects. The suitable job may be a scientist or public } \\
\text { prosecutor. } \\
\text { The judgments are influenced by the external standards } \\
\text { Theeling }\end{array}$ \\
& $\begin{array}{l}\text { Thendy and changeable } \\
\text { trenders are conservative, emotional, flighty, }\end{array}$ \\
& $\begin{array}{l}\text { Interested in interacting with the external world. } \\
\text { Sensation }\end{array}$ \\
& $\begin{array}{l}\text { Finding the chances in the external world. They are } \\
\text { suitable as speculator or entrepreneur. }\end{array}$
\end{tabular}

Introvert

Interpreting and understanding their own ideas. The suitable job may be a philosopher, a theorist or absent-minded professor

The judgments are not influenced by the external standards but based on own standards. Usually their views are not in line with public opinion. Their characters are reserved, cold, and unchangeable.

Interested in enjoying own inner self. Emphasizing introversion and intuition unconsciously

Finding the chances within own inner self. They are suitable as a mystical dreamer, self-styled prophet, or 'misunderstood experts' 


\section{RESEARCH METHODOLOGY}

\section{Research Design}

This research was carried out by applying a quantitative approach with an experimental design. The design used in this study was $2 \times 2$ factorial one since it observes more than one variable. In this research, there are two independent variable: the first independent variable was teaching techniques, which are two kinds: Roundtable and Clustering teaching techniques as a Cooperative Learning, and the second independent variable was personal traits, they are extrovert and introvert. While dependent variable was the students' achievement in writing. Thus, the research design is two- way ANOVA (Analysis of Variance).

\section{Population and Sample}

The population of this research was all grades nine in SMP N 2 Pancurbatu consisting seven classes. Each class consists of 40 students; it means that 280 students were used as the population of this research. The sample was chosen by using cluster random sampling, because they were classes not the students. IX 1 consists of 40 students was used as the experimental group so that it was taught by Roundtable teaching technique, Meanwhile, IX 2 containing 40 students was used as the control group so that it was taught by Clustering teaching technique. Therefore, the total number of the students as the sample of this research was 80 students.

\section{Experimental Procedures}

The students are in the same school, grade and range of age. They also have the same length of time for the treatment that was $2 \times 45$ minutes. The treatment was conducted in twelve meetings. The test was given twice; the first test is the questionnaire of personal traits that have been administered before and after treatments. It is ensured that the students do not know that they were treated in an experiment. The two groups were given the same materials, which were taught by different teaching techniques. The first group was taught by Roundtable teaching technique and the second one by Clustering teaching technique.

\section{RESULT AND FINDINGS}

\section{Testing Hypothesis}

The hypothesis of this research is verified by two-way analysis of variance (ANOVA) with factorial design. Thus the data description is seen as this following Table 3.1.

This data description with factorial design is used for further calculation of two way ANOVA and that the result is as the following Table 3.2.

This data description with factorial design is used for further calculation of two-way ANOVA.

\section{The Effect of Teaching Techniques on Students' Writing Achievement}

The calculation of the effect of Roundtable and Clustering teaching technique is as follows in Table 3.3.

Regardless of students' personal trait, students who were taught writing by using Roundtable teaching technique, $77,98 \pm 5,89$, had higher score compared to the students who were taught by using Clustering teaching technique,

Table 3.1. Two-Way ANOVA with $2 \times 2$ Factorial

\begin{tabular}{|c|c|c|c|}
\hline \multirow[t]{2}{*}{ Personal Traits (A) } & \multicolumn{2}{|c|}{ Teaching Techniques (B) } & \multirow[t]{2}{*}{ TOTAL } \\
\hline & Roundtable (B1) & Clustering (B2) & \\
\hline \multirow[t]{3}{*}{ Introvert (A1) } & N Y $=26$ & $\mathrm{~N} \mathrm{Y}=18$ & $\mathrm{~N} Y=44$ \\
\hline & $\sum \mathrm{Y}=1931$ & $\sum \mathrm{Y}=1265$ & $\sum \mathrm{Y}=3196$ \\
\hline & $y=287,12$ & $Y=237,61$ & $Y=524,73$ \\
\hline \multirow[t]{3}{*}{ Extrovert (A2) } & N Y=14 & $\mathrm{N} \mathrm{Y}=22$ & $\mathrm{~N} \mathrm{Y}=36$ \\
\hline & $\sum=977$ & $\sum=1565$ & $\sum \mathrm{Y}=25442$ \\
\hline & $Y=236,36$ & $Y=498,59$ & $\mathrm{Y}=734,95$ \\
\hline \multirow[t]{3}{*}{ Total } & $\mathrm{N} \mathrm{Y}=40$ & $\mathrm{~N} \mathrm{Y}=40$ & $\mathrm{~N} \mathrm{Y}=80$ \\
\hline & $\sum \mathrm{Y}=2908$ & $\sum \mathrm{Y}=2830$ & $\sum \mathrm{Y}=5738$ \\
\hline & $Y=523,47$ & $Y=736,20$ & $Y=1259,67$ \\
\hline
\end{tabular}

This data description with factorial design is used for further calculation of two way ANOVA

Table 3.2. The calculation of the Two-Way ANOVA

\begin{tabular}{lcccccc}
\hline Score of Variance & JK & Df & RJK & F observed & Ftable=F 0,05: 1:76 & Description \\
\hline Personal Traits (A) & 76,05 & 1 & 76,05 & 4,59 & Significant \\
Teaching Techniques (B) & 81,21 & 1 & 81,21 & 4,90 & Significant \\
Interaction of AB & 109,01 & 1 & 109,01 & 6,58 & Significant \\
Error & 1260 & 76 & 16,57 & - & Significant \\
Total & 1525,95 & 79 & - & - & \\
\hline
\end{tabular}

This data description with factorial design is used for further calculation of two-way ANOVA. 
$72,95 \pm 6,66$. In addition, the result of ANOVA test shows that Fobserved $>$ Ftable in which the Fobserved is 4,59 and Ftable is 3,97. Therefore, the null hypothesis was rejected. Thus, student gained $6,85 \%$ more score when taught by using Roundtable teaching technique to students using Clustering teaching technique. As a result, the students' achievement in descriptive writing taught by Roundtable teaching technique is higher than taught by Clustering teaching technique is true.

\section{The Effect of Personal Traits on Students' Writing Achievement}

The calculation of the effect of Introvert and Extrovert students on Students' writing achievement is as follows in Table 3.4.

Writing Achievement of students with introvert personal trait, $73.600 \pm 12.68$, had higher score compared to student's writing achievement with extrovert personal trait, $66.28 \pm 10$, 87. The test was needed to strengthen the interaction from each combination between teaching techniques and students' personal traits. The test done here is Tuckey-test. The result of the test is concluded as follows:

1. The mean of students with introvert personal trait taught by using Roundtable teaching technique is higher than

Table 3.3. The calculation of the effect of Roundtable and Clustering teaching technique

\begin{tabular}{lcc}
\hline Data & $\begin{array}{c}\text { Roundtable } \\
\text { Teaching Technique }\end{array}$ & $\begin{array}{c}\text { Clustering } \\
\text { Teaching Technique }\end{array}$ \\
\hline $\mathrm{N}$ & 40 & 40 \\
Maximum & 88 & 85 \\
Minimum & 70 & 65 \\
Range ${ }^{\circledR}$ & 18 & 20 \\
Mean & 77,98 & 72,95 \\
Median & 80,00 & 73,00 \\
Mode & 74,00 & 69,00 \\
Variance & 34,64 & 44,31 \\
Standard & 5,89 & 6,66 \\
Deviation & & \\
\hline
\end{tabular}

Table 3.4. Table The calculation of the effect of Introvert and Extrovert students on Students'writing

\begin{tabular}{lcc}
\hline Data & Introvert (A1) & Extrovert (A2) \\
\hline $\mathrm{N}$ & 40 & 40 \\
Maximum & 88 & 78 \\
Minimum & 40 & 48 \\
Range ${ }^{\circledR}$ & 48 & 30 \\
Mean & 73,60 & 66,28 \\
Median & 78,00 & 64,00 \\
Mode & 78,00 & 76,00 \\
Variance & 160,86 & 118,26 \\
Standard Deviation & 12,68 & 10,87 \\
\hline
\end{tabular}

the mean of students with extrovert personal trait taught by using Roundtable teaching technique;

2. The mean of students with introvert personal traits taught by using Roundtable teaching technique is higher than the mean of students with introvert personal trait taught by using Clustering teaching technique;

3. The mean of students with extrovert personal trait taught by using Clustering teaching technique is higher than the students with introvert personal trait taught by using Clustering teaching technique.

4. The mean of students with extrovert personal trait taught by using Roundtable teaching technique is higher than the mean of students with introvert personal trait taught by using Clustering teaching technique;

5. The mean of students with extrovert personal trait taught by using Clustering teaching technique is higher than the mean of students with extrovert personal trait taught by using Roundtable teaching technique.

Findings

In findings of this study indicate that introvert students are better in their achievement in descriptive writing that is shown by total mean of both personal traits on the average. In addition, the data analysis shows that students with introvert personal trait have higher achievement than students with extrovert personal trait. It means that students with introvert personal trait have higher achievement in descriptive writing than those students with extrovert personal trait.

\section{CONCLUSION AND SUGGESTION}

\section{Conclusion}

Based on the data analysis and the research findings, it is concluded that:

1. Students' achievement in descriptive writing by using Roundtable teaching technique is higher than that taught by using Clustering teaching technique.

2. The introvert of students have higher achievement than students extrovert personal traits;

3. There is significant interaction between teaching techniques and personal traits on students' achievement in descriptive writing. On the other words, it can be said that the students' achievement in descriptive writing is influence by the teaching techniques and students' personal traits.

\section{Suggestions}

There are some suggestions related to the conclusions at the previous page. They are:

- It is suggested for the teachers to use Roundtable and Clustering teaching techniques since these two teaching techniques are able to improve students' achievement in descriptive writing.

- It is suggested for the teachers to use Roundtable teaching technique for a classroom dominated by students with introvert personal traits.

- Teacher should realized that the students' characteristics such as their personal traits before choosing the teaching techniques. 
- Other researchers may take a further research in the area Roundtable and Clustering teaching techniques that will improve students' achievement in descriptive writing.

\section{REFERENCES}

Boardman, C.A. (2008). Writing to Communicate Paragraph and Essay. 10 Bank Street, White Plains, NY 10606: Pearson Education

Graham, S. (2006). Writing in P. Alexander \& P. Winne (Eds). Handbook of Educational Psychology (pp.457 -478). Mnawah, NJ: Erlbaum.

Hazanah, C.Y. (2003). The difficulties in Rendering Complex Sentences in Interpreting Indonesian Discourse into English Unpublished Academic Paper. Bandung: Indonesia University of Education.

Henning, E. 2005. Finding your way in Academic Writing. Hatfield, Pretoria: Van Schaik Publishers 1064 Arcadia Street.

Hyland, K. 2002. Teaching and researching Writing. Harlow: Longman

Jensen, G.H., \& Di Tiberio, J.K. 1989. Personality and the Teaching of Composition. Norwood, NJ. Ablex

Jordan, M.E. 2011. Personality Traits: Theory, Testing and Influences. Ne York: Science Publishers, In

Knapp, P. 2005. Genre, Text, Grammar. Peter Knapp. Australia; University of New South Wales Press Ltd. www. unswpress.com.au
Kyriacou, C. 2009. Effective Teaching in Schools Theory and Practice. Delta Place United Kingdom: Nelson Thornes. Manser, M. H. (2006). Guide to Good Writing. New York: Libraryof Congress Cataloging-in-Publication Data.

Nazario, L.A.,2010. Bridges to Better Writing. Wadsworth 20 Channel Center Street Boston, MA 02210.Canada; by Nelson Education

Naik, A. (2010). Introvert Personality. Retrieved on December 10, 2013 from www.buzzle.com/article/introvertpersonality.html.

Raymond, C.1980. Writing (Is Unnatural Act). New York: Harper \& Row

Rico, G.2000.Writing the Natural Way. New York: Penguin Putnam Inc.

Richards, J. C. \& Schmidt, R. W. (2002). Dictionary of Language Teaching and Applied Linguistics. NY \& London: Longman.

Styati, E.W.2010. The Effectiveness of Clustering Technique to Teach Writing Skill Viewed from Students'Linguistics Intelligence (An experimental Research on Descriptive Writing for the Second Semester of English Departement of IKIP PGRI Madiun the Academic Year of 2009/2010) Surakarta: Universitas Sebelas Maret

Weigle, S.C.2002. Assesing Writing. United Kingdom, Cambridge: Cambridge University Press

Zemach,D.E at al.2009. Academic Writing from Paragraph to Essay. Cambridge: The Cambridge University Press. The Edinburgh Building, Cambridge CB2\&RU 